\title{
The Use of Pressure Drop Measurements for Estimating Ventilation and Paper Porosity*
}

\author{
by C. H. Keith \\ Celanese Fibers Company, Charlotte, North Carolina, U.S.A.
}

The recent increase in the number and volume of ventilated cigarette brands has created a need for a simple, non-destructive means of measuring the degree of air dilution. Two techniques currently in use require the use of auxiliary equipment or specialized analyses. One of these is the sleeve method of Norman (1) which encloses the ventilation portion of the cigarette in a small chamber and measures the flow into this chamber while a puff or alternatively a constant flow is withdrawn from the cigarette. The degree of air dilution is thus estimated from the ratio of the volumetric flow rates. A second method is that described by Reynolds and Wheeler (2), which encloses the cigarette except for the burning coal in an atmosphere of argon. The amount of argon in the mainstream smoke provides a measure of the dilution.

Since both of these techniques require enclosing the burning or unlit cigarette in a chamber and separating the diluting flow from the mainstream flow by means of seals, they can sometimes be difficult to use in routine measurements. A method which avoids these difficulties is to utilize the encapsulated and unencapsulated pressure drop of the unlit or lit cigarette to estimate the amount of air dilution. Since pressure drop and volumetric air flow are essentially directly proportional to each other in cigarette filters $(3,4)$, the difference between the encapsulated and unencapsulated pressure drop provides a measure of the degree of filter ventilation. This was recognized by Reif (5), who derived the appropriate equations for a ventilated filter. While it is known that pressure drop in a tobacco rod is only approximately proportional to flow, the non-linear effects are small enough so that pressure drops can also be used to estimate ventilation in this portion of the cigarette.

Figure 1 illustrates the dilution processes occurring in a cigarette, and the various pressure drop measurements that can be used to estimate these. Each of these pressure drops can be conveniently measured using an accurate pressure drop machine, and a rubber sleeve encapsulator. For the measurements reported herein, a critical flow orifice pressure drop tester with an adjustable length rod encapsulator of Celanese design was used. The orifice was calibrated to a flow of $17.50 \pm 0.15 \mathrm{ml} / \mathrm{s}$ at 760 torr and

\footnotetext{
- Presented, in part, at the Coresta Technology Study Group meeting held in Munich, Germany, in September 1977.

Received: 29th September 1978 - accepted: 6th July 1979.
}

$20^{\circ} \mathrm{C}$. For measurements on ventilated filters, the pertinent readings are the normal open cigarette pressure drop, $\Delta \mathrm{p}_{0}$, the cigarette pressure drop with the filter vents closed, $\Delta \mathrm{p}_{\mathrm{c}}$, and the filter pressure drop, $\Delta \mathrm{p}_{\mathrm{f}}$. For measurements on tobacco columns, a fully encapsulated pressure drop, $\Delta \mathrm{pe}_{\mathrm{e}}$, is also required.

The basis for the calculation of diluting air flow from pressure drop is the observation $(3,4,6,7)$ that pressure drop is essentially equal to the product of an impedance coefficient, a flow rate and a length (Darcy's Law). While this relationship is nearly exact only for filter tips, it is usable to a good approximation in tobacco columns where a more complicated flow regime exists. Using this assumption and one that pressure drops are additive, the diluting air flow for a single row of holes can be calculated by equation 1 of Figure 2. By extension of the multiple row case in equation 2 to many rows of closely spaced holes extending the length of the filter, equations for porous tipping paper or porous cigarette paper can be derived. Equa-

Figure 1. Dilution processes and pressure drop measurements.

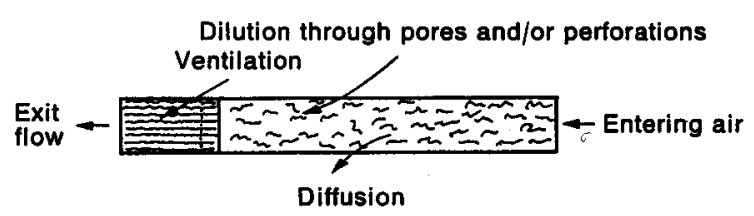

SYMBOL

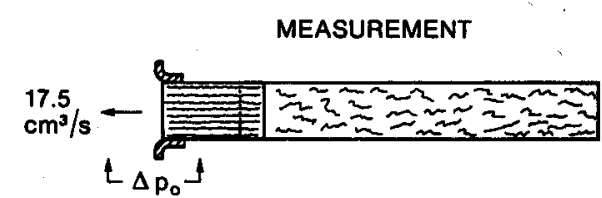

$\Delta p_{e}$

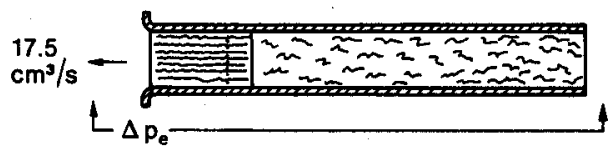

$\Delta p_{c}$

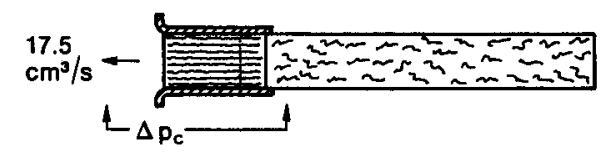

$\Delta p_{\text {f }}$

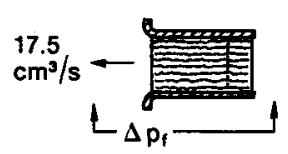


Figure 2. Dilution equations.

1. Filter dilution - single row of holes dilution $=\frac{\Delta Q}{Q}=\frac{\Delta p_{c}-\Delta p_{o}}{\Delta p_{c}-L_{1} \Delta p_{f} / L_{f}}$

2. Filter dllution - multiple rows of holes dilution $=\frac{\Delta p_{c}-\Delta p_{o}}{\Delta p_{c}-L_{i} \Delta p_{f} / L_{f}-(n-1) \Delta L \Delta p_{f} / 2 L_{f}}$

3. Fliter dilution - porous tipping paper

$$
\text { dilution }=\frac{\Delta p_{c}-\Delta p_{o}}{\Delta p_{c}-\left(L_{i}+L_{f}\right) \Delta p_{f} / 2 L_{f}}
$$

4. Column dilution - porous cigarette paper, non-porous tipping

dilution $=\frac{2\left(\Delta p_{e}-\Delta p_{c}\right)\left(L_{o}+L_{c}\right)}{\left(\Delta p_{0}-\Delta p_{f}\right) L_{o}}$

5. Column dilution - porous cigarette paper - vented filter

dilution $=\frac{2\left(\Delta p_{0}-\Delta p_{c}\right)\left(1-D_{f}\right)\left(L_{0}+L_{c}\right)}{\left(\Delta p_{c}-\Delta p_{f}\right) L_{0}}$

6. Total Dilution

dilution $=D_{f}+D_{t}$ where:

\begin{tabular}{|c|c|c|}
\hline$\Delta \mathbf{Q}$ & $=$ & diluting flow $\left(\mathrm{cm}^{3} / \mathrm{s}\right)$ \\
\hline $\mathbf{Q}$ & $=$ & total exit flow $\left(\mathrm{cm}^{3} / \mathrm{s}\right)$ \\
\hline$\Delta p_{0}$ & $=$ & $\begin{array}{l}\text { clgarette pressure drop - unencapsulated } \\
\left(\mathrm{mm} \mathrm{H}_{2} \mathrm{O}\right)\end{array}$ \\
\hline$\Delta p_{c}$ & $=$ & $\begin{array}{l}\text { clgarette pressure drop - filter encap- } \\
\text { sulated }\left(\mathrm{mm} \mathrm{H}_{2} \mathrm{O}\right)\end{array}$ \\
\hline$\Delta p_{e}$ & $=$ & $\begin{array}{l}\text { cigarette pressure drop - total encap- } \\
\text { sulation }\left(\mathrm{mm} \mathrm{H}_{2} \mathrm{O}\right)\end{array}$ \\
\hline$\Delta p_{f}$ & $=$ & $\begin{array}{l}\text { filter pressure drop - encapsulated } \\
\left(\mathrm{mm} \mathrm{H}_{2} \mathrm{O}\right)\end{array}$ \\
\hline $\mathrm{L}_{\mathbf{1}}$ & $=$ & $\begin{array}{l}\text { distance from mouth end to open vents ( } \mathrm{mm} \text { ). } \\
\text { For porous tipping this becomes the length of } \\
\text { insertion into the holder. }\end{array}$ \\
\hline$L_{f}$ & $=$ & filter length (mm) \\
\hline$\Delta \mathrm{L}$ & $=$ & distance between_rows of vents $(\mathrm{mm})$ \\
\hline $\mathrm{L}_{\varepsilon}$ & $=$ & $\begin{array}{l}\text { length of tobacco column encased in im- } \\
\text { pervious wrapping or inside the holder }(\mathrm{mm})\end{array}$ \\
\hline$L_{0}$ & $=$ & open column length (mm) \\
\hline $\mathbf{n}$ & $=$ & number of rows of vents \\
\hline$D_{f}$ & $=$ & filter dilution \\
\hline & $=$ & acco column dilution \\
\hline
\end{tabular}

tions 3 and 4 are appropriate to porous tips and columns. Equation 5 extends 4 to the case where vented filters are employed. Finally, equation 6 provides the total dilution for a cigarette. By addition of other pressure drops and lengths these can be applied to multiple filters and other constructions. The derivation of these equations is outlined in the Appendix (p. 15).

To test the validity of these equations for perforated tipping paper, Parker and Montgomery (8) measured the pertinent dilutions and pressure drops on a series of cigarettes equipped with various filters and two types of Malaucene laser-perforated tipping papers, designated M 3.0 and 1.5. Companion measurements on cigarettes with non-porous tipping were also performed. The cigarettes all had general dimensions of $85 \mathrm{~mm}$ overall length,
$30 \mathrm{~mm}$ tipping paper, $21 \mathrm{~mm}$ filter length and $25 \mathrm{~mm}$ circumference. When smoked, the butt length was $33 \mathrm{~mm}$. Those equipped with the M 3.0 tipping paper had twenty oblong holes of $0.2 \mathrm{~mm}^{2}$ area located $15 \mathrm{~mm}$ from the end of the filter, while those with the 1.5 paper had twenty holes of about $0.12 \mathrm{~mm}^{2}$ area located $12 \mathrm{~mm}$ from the mouth end. For some of Parker and Montgomery's samples, cigarette and filter pressure drops from the control nonperforated cigarettes were combined with the cigarette pressure drops for the perforated samples to calculate the dilution values for the unlit cigarettes as shown in Table 1. As is evident, the agreement between Parker and Montgomery's (8) observed and our calculated dilutions is quite good. The importance of the placement of the dilution vents is apparent here. Even though the $M 1.5$ paper had

Table 1. Calculated and measured dilutions (unlit clgarettes).

\begin{tabular}{|c|c|c|c|c|c|c|c|}
\hline Tow item & $\begin{array}{l}\text { Tipping } \\
\text { paper }\end{array}$ & $\begin{array}{c}\Delta p_{\circ}^{*} \\
\left(\mathrm{~mm} \mathrm{H}_{2} \mathrm{O}\right)\end{array}$ & $\begin{array}{c}\Delta p_{c}^{*} \\
\left(\mathrm{~mm} \mathrm{H}_{2} \mathrm{O}\right)\end{array}$ & $\begin{array}{c}\Delta p_{f}^{*} \\
\left(m m H_{2} \mathrm{O}\right)\end{array}$ & $\begin{array}{c}\text { Calculated } \\
\text { dilution } \\
(\%)\end{array}$ & $\begin{array}{c}\text { Observed } \\
\text { dilution * } \\
(\%)\end{array}$ & 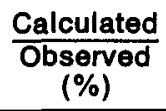 \\
\hline $1.6 R / 50$ & $\begin{array}{l}M 3.0 \\
M 1.5\end{array}$ & $\begin{array}{r}102 \\
104\end{array}$ & $\begin{array}{l}162 \\
162\end{array}$ & $\begin{array}{l}99 . \\
99\end{array}$ & $\begin{array}{l}66 \\
55\end{array}$ & $\begin{array}{l}57 \\
55\end{array}$ & $\begin{array}{l}116 \\
100\end{array}$ \\
\hline $1.8 Y / 42$ & $\begin{array}{l}\text { M } 3.0 \\
\text { M } 1.5\end{array}$ & $\begin{array}{l}97 \\
98\end{array}$ & $\begin{array}{l}143 \\
143\end{array}$ & $\begin{array}{l}90 \\
90\end{array}$ & $\begin{array}{l}58 \\
49\end{array}$ & $\begin{array}{l}59 \\
50\end{array}$ & $\begin{array}{l}98 \\
98\end{array}$ \\
\hline $2.5 Y / 48$ & $\begin{array}{l}\text { M } 3.0 \\
M 1.5\end{array}$ & $\begin{array}{l}93 \\
91\end{array}$ & $\begin{array}{l}142 \\
142\end{array}$ & $\begin{array}{l}90 \\
90\end{array}$ & $\begin{array}{l}63 \\
56\end{array}$ & $\begin{array}{l}62 \\
59\end{array}$ & $\begin{array}{r}102 \\
95\end{array}$ \\
\hline $5.0 Y / 40$ & $\begin{array}{l}\text { M } 3.0 \\
\text { M } 1.5\end{array}$ & $\begin{array}{l}63 \\
66\end{array}$ & $\begin{array}{l}96 \\
96\end{array}$ & $\begin{array}{l}49 \\
49\end{array}$ & $\begin{array}{l}54 \\
44\end{array}$ & $\begin{array}{l}51 \\
45 \\
\text { ave }\end{array}$ & $\begin{array}{r}106 \\
98 \\
102\end{array}$ \\
\hline
\end{tabular}

\footnotetext{
* : Data from Parker and Montgomery (8).
} 
Table 2. Dellverles and removal efficlencies. *

\begin{tabular}{|c|c|c|c|c|c|c|c|c|c|}
\hline Filter & $\begin{array}{c}\text { Tipping } \\
\text { paper }\end{array}$ & $\begin{array}{c}\text { Calcu- } \\
\text { lated } \\
\text { dilution } \\
(\%)\end{array}$ & $\begin{array}{l}\text { No. of } \\
\text { puffs }\end{array}$ & $\begin{array}{l}\text { Smoke * } \\
\text { (mg/cig.) }\end{array}$ & $\begin{array}{c}\text { Smoke } \\
\text { removal } \\
\text { efficiency } \\
(\%)\end{array}$ & $\begin{array}{c}\text { Conden- } \\
\text { sate+ } \\
\text { (mig/cig.) }\end{array}$ & $\begin{array}{c}\text { Conden- } \\
\text { sate } \\
\text { removal } \\
\text { efficiency } \\
(\%)\end{array}$ & $\begin{array}{c}\text { Carbon } \\
\text { monoxide } \\
\text { (mg/cig.) }\end{array}$ & $\begin{array}{l}\text { Conden- } \\
\text { sate/CO }\end{array}$ \\
\hline & non-porous & 0 & 8.2 & 16.5 & 60.1 & 13.4 & 53.0 & 17.5 & 0.766 \\
\hline \multirow[t]{3}{*}{$1.6 \mathrm{R} / 50$} & M 3.0 & 66 & 9.6 & 6.0 & 61.9 & 5.2 & 60.9 & 7.1 & 0.732 \\
\hline & M 1.5 & 55 & 9.2 & 7.4 & 61.8 & 6.4 & 59.8 & 7.9 & 0.810 \\
\hline & non-porous & 0 & 7.8 & 17.5 & 56.7 & 14.2 & 49.6 & 18.2 & 0.780 \\
\hline \multirow[t]{3}{*}{$1.8 Y / 42$} & M 3.0 & 58 & 9.8 & 6.9 & 59.8 & 5.9 & 59.1 & 7.1 & 0.831 \\
\hline & M 1.5 & 49 & 9.2 & 8.2 & 58.6 & 7.1 & 56.8 & 8.5 & 0.835 \\
\hline & non-porous & 0 & 7.8 & 18.0 & 57.1 & 14.6 & 49.6 & 17.6 & 0.830 \\
\hline \multirow[t]{2}{*}{$2.5 Y / 48$} & M 3.0 & 63 & 9.4 & 5.8 & 59.1 & 5.1 & 60.2 & 5.8 & 0.879 \\
\hline & M 1.5 & 56 & 9.5 & 7.0 & 58.2 & 6.0 & 57.0 & 6.4 & 0.938 \\
\hline . & non-porous & 0 & 7.1 & 21.3 & 43.4 & 17.4 & 34.7 & 18.3 & 0.951 \\
\hline \multirow[t]{2}{*}{$5.0 Y / 40$} & M 3.0 & 54 & 9.1 & 12.0 & 41.0 & 9.5 & 30.7 & 7.8 & 1.22 \\
\hline & M 1.5 & 44 & 9.1 & 12.8 & 41.9 & 11.1 & 38.1 & 9.0 & 1.23 \\
\hline
\end{tabular}

: Data from Parker and Montgomery (8).

* : Particulate matter retained on a Cambridge filter pad.

+ : Nicotlne-Iree dry smoke.

approximately $60 \%$ the hole area of the M 3.0 paper, this did not reduce the dilution by as much as might be expected. The reason for this is that the holes on the $M 1.5$ paper were located closer to the mouth end of the cigarette, thereby placing more pressure drop upstream of the vents. Thus the pressure drop across the vents is increased, providing more flow through them than might be expected on the basis of hole size alone. This effect is illustrated in a calculated plot of percent dilution versus hole position as shown in Figure 3 for the $2.5 \mathrm{Y} / 48$ filter with $M 1.5$ paper. This figure also shows the calculated cigarette pressure drop as the vents are moved along the filter. The values in Figure 3 were obtained by equating the diluting flow estimated from equation 1 of Figure 2 with the orifice flow through the dilution holes estimated by Selke and Mathews' (9) equation with an exponent of one half. The resulting quadratic equation is solved for $\Delta p_{0}$, and this value is reintroduced into equation 1 to obtain the calculated dilutions. As can be seen, the dilution decreases and the pressure drop markedly increases as the ventilation site is moved away from the mouth end.

To ascertain the effect of these diluting flows on smoke composition, the deliveries of particulate matter, (nicotine-free dry smoke) condensate and carbon monoxide were determined for these cigarettes including the nonporous controls, and removal efficiencies for smoke and condensate were also measured by Parker and Montgomery (8). The pertinent data are summarized in Table 2. As noted by them, it is readily apparent that the ventilated filters reduce the delivery of smoke, condensate and carbon monoxide by $35 \%$ to $65 \%$ depending on the filter and component measured. Also, as can be predicted from filtration theory, introduction of diluting air into the filter generally slightly increases the removal efficiencies, particularly for dry condensate. This occurs because the smoke is drawn through the front part of the filter at a slower rate, i.e. there is a reduced volume passing through this part of the filter in the same period of time. Since diffusion, the major filtration mechanism, is more effective at lower velocities, the efficiencies will increase, as was found by Overton (10) and Keith (11). The effect is less marked for smoke removal efficiency as the slower flow rate also allows a great adsorption of vapor phase

Figure 3. Calculated effect of hole position on dilution.

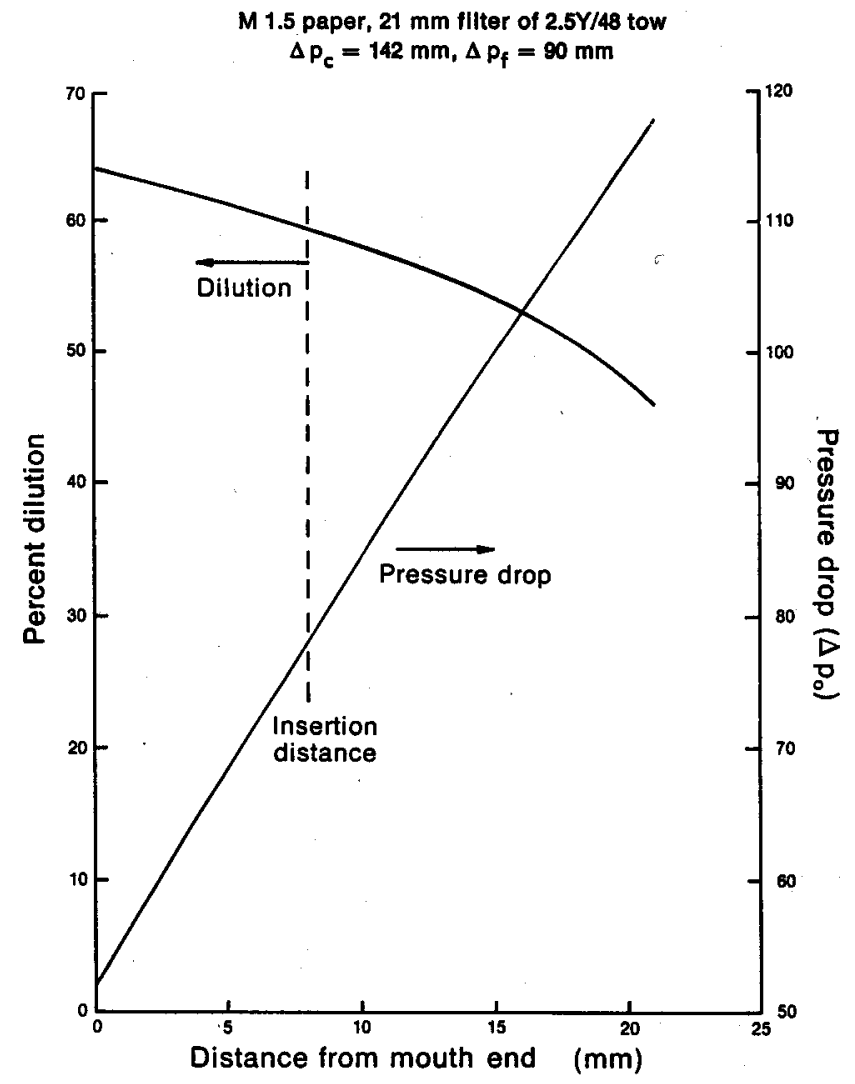


Table 3. Particulate matter (observed and expected deliverles).

\begin{tabular}{l|c|c|c|c}
\hline Filter & $\begin{array}{c}\text { Tipping } \\
\text { paper }\end{array}$ & $\begin{array}{c}\text { Observed } \\
\text { delivery } \\
\text { (mg/cig.) }\end{array}$ & $\begin{array}{c}\text { Expected } \\
\text { delivery } \\
\text { (mg/cig.) }\end{array}$ & $\begin{array}{c}\text { Expected } \\
\text { Observed } \\
(\%)\end{array}$ \\
\hline \multirow{3}{*}{$1.6 \mathrm{R} / 50$} & M 3.0 & 6.0 & 6.3 & 105 \\
& M 1.5 & 7.4 & 8.0 & 108 \\
$1.8 Y / 42$ & M 3.0 & 6.9 & 8.6 & 124 \\
& M 1.5 & 8.2 & 10.4 & 123 \\
$2.5 Y / 48$ & M 3.0 & 5.8 & 5.9 & 101 \\
& M 1.5 & 7.0 & 7.3 & 104 \\
$5.0 Y / 40$ & M 3.0 & 12.0 & 13.1 & 109 \\
& M 1.5 & 12.8 & 15.7 & 122 \\
& & & \multicolumn{3}{c}{ average 112} \\
\hline
\end{tabular}

*: Data from Parker and Montgomery (8).

water in the tobacco butt preceding the filter (12), thereby reducing the adsorption component of the filter smoke removal efficiency.

Using these efficiencies and the dilution percentages, it is possible to calculate the smoke, condensate and carbon monoxide deliveries that would be expected if only dilution and filtration were operative. Since different numbers of puffs were taken on the ventilated and non-ventilated cigarettes, these expected deliveries have to be adjusted to a common number of puffs by multiplication by puff count ratios. This comparison is shown for wet particulate matter in Table 3. For this smoke component, the observed values are generally less than the calculated values, the average calculated to observed ratio being $112 \%$. This discrepancy is expected since this measure includes water and some water vapor. As has been indicated, water can be more effectively adsorbed by the tobacco column and in the filter in the ventilated cigarette because of their lower flow rates. This adsorption reduced the delivery below that which would be expected if only dilution and straight filtration were effective.

Table 4 shows a comparison of observed and expected deliveries for nicotine-free dry particulate matter or condensate. Here it is evident that the agreement between the

Table 4. Condensate (observed and expected dellverles).

\begin{tabular}{l|c|c|c|c}
\hline Filter & $\begin{array}{c}\text { Tipping } \\
\text { paper }\end{array}$ & $\begin{array}{c}\text { Observed } \\
\text { delivery } \\
\text { (mg/clg.) }\end{array}$ & $\begin{array}{c}\text { Expected } \\
\text { delivery } \\
\text { (mg/cig.) }\end{array}$ & $\begin{array}{c}\text { Expected } \\
\text { Observed } \\
(\%)\end{array}$ \\
\hline \multirow{3}{*}{$1.6 \mathrm{R} / 50$} & M 3.0 & 5.2 & 4.6 & 89 \\
& M 1.5 & 6.4 & 5.8 & 91 \\
$1.8 Y / 42$ & M 3.0 & 5.9 & 6.1 & 103 \\
& M 1.5 & 7.1 & 7.3 & 103 \\
$2.5 Y / 48$ & M 3.0 & 5.1 & 5.2 & 102 \\
& M 1.5 & 6.0 & 6.7 & 112 \\
$5.0 Y / 40$ & M 3.0 & 9.5 & 10.9 & 115 \\
& M 1.5 & 11.1 & 11.8 & 106 \\
& & \multicolumn{3}{c}{ average 103} \\
\hline
\end{tabular}

* : Data from Parker and Montgomery (8).
Table 5. Carbon monoxide (observed and expected dellverles).

\begin{tabular}{l|c|c|c|c}
\hline Filter & $\begin{array}{c}\text { Tipping } \\
\text { paper }\end{array}$ & $\begin{array}{c}\text { Observed } \\
\text { delivery } \\
\text { (mg/cig.) }\end{array}$ & $\begin{array}{c}\text { Expected } \\
\text { delivery } \\
\text { (mg/cig.) }\end{array}$ & $\begin{array}{c}\text { Expected } \\
\text { Observed } \\
(\%)\end{array}$ \\
\hline \multirow{2}{*}{$1.6 \mathrm{R} / 50$} & M 3.0 & 7.1 & 7.0 & 99 \\
& M 1.5 & 7.9 & 8.8 & 111 \\
$1.8 Y / 42$ & M 3.0 & 7.1 & 9.6 & 135 \\
& M 1.5 & 8.5 & 11.0 & 129 \\
$2.5 Y / 48$ & M 3.0 & 5.8 & 7.9 & 136 \\
& M 1.5 & 6.4 & 9.4 & 147 \\
$5.0 Y / 40$ & M 3.0 & 7.8 & 10.8 & 138 \\
& M 1.5 & 9.0 & 13.1 & 145 \\
& & & \multicolumn{2}{c}{ average 130} \\
\hline
\end{tabular}

" : Data from Parker and Montgomery (8).

measured and calculated values is quite good, averaging $103 \%$. This provides an indication that most if not all of the difference between the vented and unvented cigarettes can be ascribed to the dilution process and its effects on filtration and burning rate. There does not seem to be any great differences in tobacco column adsorption of condensate components or a significant change in the mix of condensed smoke components generated by the slower burning tobacco in the vented cigarettes.

Table 5 shows comparable observed and calculated carbon monoxide deliveries, and here again the agreement is not good, averaging $130 \%$. This indicates an increased loss of carbon monoxide by diffusion through the cigarette paper and vents, as was found by Morie (13), Baker and Crellin (14), Owen and Reynolds (15) and Muramatsw et al. (16).

It may be noted for condensate that the calculated values are on the average slightly higher than the observed values. This can occur because the amount of dilution increases once the cigarette is lighted. This increase comes from the increased pressure drop of the burning cone. This increased pressure drop in the tobacco column ahead of the ventilation holes causes more air to be drawn through the vents, thereby increasing the overall dilution. This effect was measured by making pressure drop measurements on a commercial ventilated cigarette during smoking by connecting the cigarette to a constant flow pressure drop machine for two seconds once a minute, thereby using the pressure drop machine as a smoking machine, as shown in Figure 4. This cigarette had an unlit pressure drop of $114 \mathrm{~mm}$ of water, which increased to a fairly constant value of 123-125 mm for the first six puffs after lighting. In the last two puffs for this cigarette the pressure drop again increased up to $139 \mathrm{~mm}$, probably because of an increase in the temperature of the smoke stream entering the filter. This pattern is similar to that found by Baker (7). Using these pressure drops and those obtained on comparable cigarettes with the filter vents closed, the dilutions shown in Figure 5 were calculated. This calculation assumes that the pressure drop increase in the latter puffs is occurring in the filter, which appears to be reasonable. It is evident that, as expected, the dilution increases 
Figure 4. Smoking pressure drop apparatus (square wave pufi).

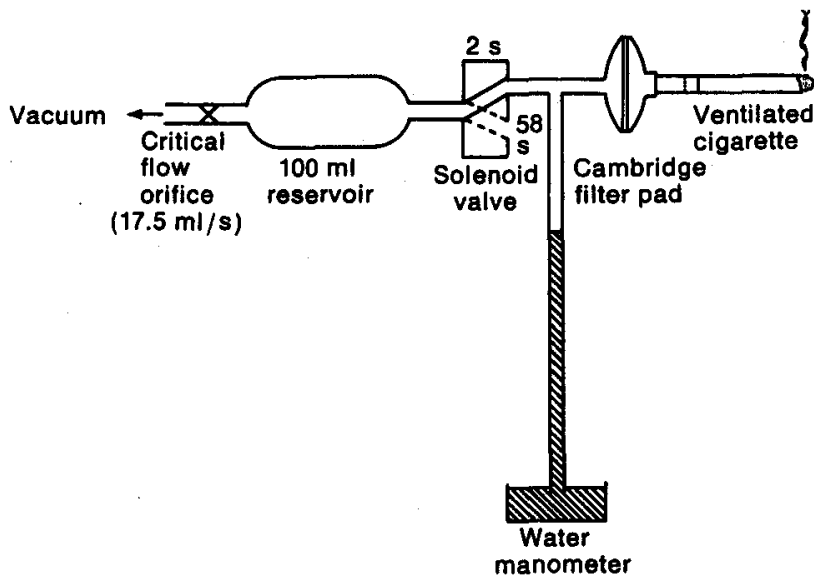

once the cigarette is lit. Because of the relatively constant pressure drop, it does not appreciably change during most of the smoking process. In the last puff or two the dilution again increases for this cigarette, somewhat offsetting the higher deliveries of smoke components in these puffs.

As a further test of the validity of measurement of dilution by pressure drop, six commercial vented filter brands were examined. Table 6 lists measured and calculated filter dilutions for these cigarettes, and in addition the total dilution for both the filter and tobacco column is calculated from pressure drop readings. In Table 6 it is again apparent that there is reasonable agreement between the measured and calculated dilutions although the calculated values are generally slightly higher than the measured values. This discrepancy is thought to arise from the small internal pressure drop of the automatic dilution measuring apparatus used in this series of tests. This small pressure drop would serve to slightly reduce the diluting flow thereby giving lower dilution values. The brands measured covered a wide range of filter dilutions and had a variety of ventilation systems, which further supports the prop-

Table 6. Measured and calculated dilutions.

\begin{tabular}{|c|c|c|c|c|c|}
\hline \multirow[b]{2}{*}{ Brand } & \multirow[b]{2}{*}{$\begin{array}{c}\text { Type of } \\
\text { filter dilution }\end{array}$} & \multicolumn{2}{|c|}{ Filter dilution } & \multirow{2}{*}{$\begin{array}{c}\text { Column } \\
\text { dilution } \\
\text { (calc.) } \\
(\%) \\
\end{array}$} & \multirow{2}{*}{$\begin{array}{c}\text { Total } \\
\text { dilution } \\
\text { (calc.) } \\
(\%)\end{array}$} \\
\hline & & $\begin{array}{c}\text { meas- } \\
\text { ured } \\
(\%)\end{array}$ & $\begin{array}{c}\text { cal- } \\
\text { culated } \\
(\%)\end{array}$ & & \\
\hline A & $\begin{array}{l}\text { Single row of } \\
\text { vents }\end{array}$ & 13 & 18 & 5 & 23 \\
\hline B & $\begin{array}{l}\text { Single row of } \\
\text { vents (plastic } \\
\text { sleeve) }\end{array}$ & 16 & 17 & 9 & 26 \\
\hline C & $\begin{array}{l}\text { Single row of } \\
\text { vents }\end{array}$ & 30 & 31 & 9 & 40 \\
\hline D & $\begin{array}{l}\text { Four rows of } \\
\text { vents }\end{array}$ & 68 & 70 & 5 & 75 \\
\hline E & $\begin{array}{l}\text { Five rows of } \\
\text { vents }\end{array}$ & 46 & 51 & 8 & 59 \\
\hline$F$ & Porous tipping & 49 & 53 & 8 & 61 \\
\hline
\end{tabular}

Flgure 5. Changes In dilution during smoking.

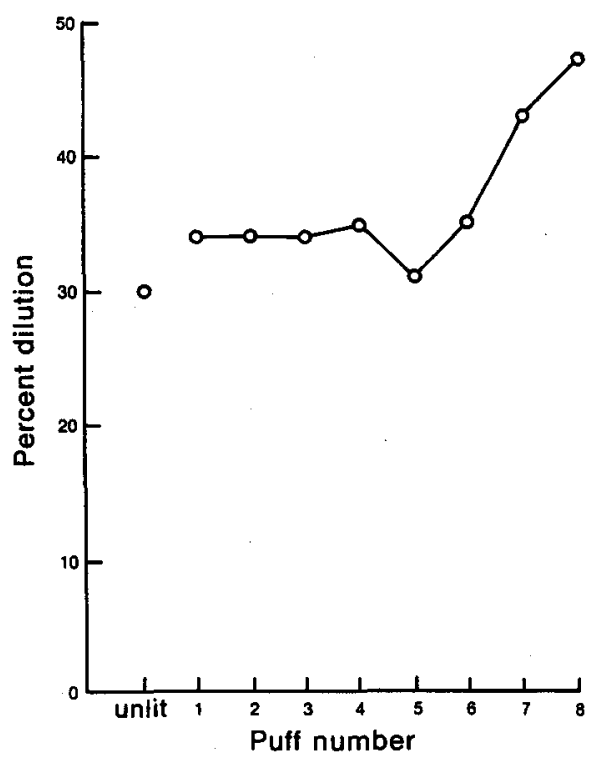

osition, that dilution can be effectively measured by simple, non-destructive pressure drop measurements.

In the measurements reported so far, and in the derivation of the equations, the only assumptions have been that the pressure drop along a tobacco column is linearly proportional to length and flow rate and that pressure drops of segments are additive. No assumption has been made as to the nature of the flow through the -vents or porous paper. As has been pointed out by Selke and co-workers $(9,17)$, this can be a combination of capillary flow where flow rate is directly proportional to pressure drop, and orifice flow where flow rate is a function of the square root of pressure drop. If we assume that only capillary flow occurs in porous tipping and cigarette paper, it is possible to analytically derive pressure drop and dilution equations as was shown by Meyer-Abich (6). It is also theoretically possible to treat cases where orifice flow is the only flow regime present or where combinations of the two exist, but the solutions of the differential equations are very complex and difficult to handle except by numerical techniques.

In the case of capillary or viscous flow only, combination of the differential equations describing flow through the porous wrapper and pressure drop along the column results in a second order differential equation describing pressure drop as a function of length. Solution of this results in the first two equations given in Figure 6. The first equation is essentially that described by Fordyce, Hughes and Ivinson and others $(3,6,17)$, and the second gives the fractional dilution. The third equation is obtained from the first by using the first two terms of the series expansion of the hyperbolic tangent and substitution of terms containing the encapsulated pressure drop for the impedance coefficient. The last equation provides the bradketed term in the third equation in terms of measurable pressure drops and lengths. With these equations it is thus possible to measure the paper porosity of a finished cigarette and the amount of dilution occurring in the tobacco column. If a porous plug wrap is also used, additional terms can be 
PRESSURE DROP:

1. $\Delta p_{0}=\Delta p_{f}+Q \cdot \frac{\alpha}{\gamma C} \tanh \left(\alpha L_{0}\right)+\frac{K \cdot Q}{A} \cdot L_{c}$

where:

$$
\begin{aligned}
& \left.\Delta p_{0}\right)=\text { the unencapsulated cigarette and the filter } \\
& \left.\Delta p_{f}\right\}=\text { pressure drops }\left(\mathrm{mm} \mathrm{H}_{2} \mathrm{O}\right) \text {, } \\
& Q=\text { volumetric flow rate }\left(\mathrm{cm}^{3} / \mathrm{s}\right) \text {, } \\
& \alpha=\text { combined constant }=\sqrt{\frac{K \gamma C}{A}}\left(\mathrm{~cm}^{-1}\right) \text {, } \\
& \mathrm{K}=\text { Impedance coefficient, tobacco column } \\
& \text { ( } \mathrm{mm} \mathrm{H}_{2} \mathrm{O} \cdot \mathrm{s} \cdot \mathrm{cm}^{-2} \text { ), } \\
& \gamma=\text { porosity coefficient }\left(\frac{\mathrm{cm}}{\mathrm{smm} \cdot \mathrm{H}_{2} \mathrm{O}}\right) \text {, } \\
& \text { C = circumference }(\mathrm{cm}) \text {, } \\
& \text { A = column area }\left(\mathrm{cm}^{2}\right) \text {, } \\
& \mathrm{L}_{0}=\text { open column length (cm), } \\
& L_{c}=\text { overwrapped column length less filter }
\end{aligned}
$$

added to the equations or they can be used as is with composite impedance and porosity coefficients. However it is generally simpler to consider the filter and the tobacco column separately in such cases with due consideration of the interactions between the components. For the tobacco column dilution alone $\Delta \mathrm{p}_{\mathrm{c}}$ is used in place of $\Delta \mathrm{p}_{\mathrm{o}}$ in all the equations. To measure the filter dilution component, $\Delta \mathrm{p}_{\mathrm{c}}$ minus $\Delta \mathrm{p}_{\mathrm{f}}$ replaced $\Delta \mathrm{p}_{\mathrm{f}}$ in equation 1 . In the third and fourth equations, $\Delta \mathrm{p}_{0}$ replaces $\Delta \mathrm{p}_{\mathrm{e}}$ in the numerator, and $\Delta \mathrm{p}_{\mathrm{f}}$ replaces $\Delta \mathrm{p}_{\mathrm{e}}-\Delta \mathrm{p}_{\mathrm{f}}$ in the denominator.

To test the validity of these equations and the assumption that capillary flow is predominant, the appropriate pressure drop measurements were made on two commercial cigarettes, one with a normal porosity paper wrapper, and one equipped with a perforated high porosity wrapper. Both had non-porous tipping paper, and two different lengths of the normal porosity brand were measured. For both cigarettes the paper porosity was measured independently by measuring the pressure drop across a $6.45 \mathrm{~cm}^{2}$ area at a flow of $200 \mathrm{~cm}^{3} / \mathrm{min}$. Table 7 compares the results of these measurements with the values calculated
DILUTION:

2. $\frac{\Delta Q}{Q}=1-\operatorname{sech}\left(\alpha \cdot L_{0}\right)$.

But by expanding the hyperbolic tangent in series, it is found that:

3. $\gamma=\frac{3 Q \cdot\left(\Delta p_{0}-\Delta p_{0}\right) \cdot\left(L_{0}+L_{c}\right)^{2}}{\left(\Delta p_{0}-\Delta p_{f}\right)^{2} \cdot C \cdot L_{0}^{3}}$

and

4. $\alpha L_{0}=\sqrt{\frac{3\left(\Delta p_{e}-\Delta p_{0}\right) \cdot\left(L_{0}+L_{c}\right)}{\left(\Delta p_{0}-\Delta p_{f}\right) \cdot L_{0}}}$,

where:

$\Delta \mathrm{p}_{\mathrm{e}}=$ encapsulated pressure drop.

by equation three. Considering the small differences between the encapsulated and unencapsulated pressure drops, the agreement between the calculated and directly measured values seems adequate. For these two brands and for brands A-F, Table 8 compares tobacco column dilutions calculated by the previous generalized pressure drop equations with those obtained from the equations of Figure 6. These calculations were performed using pressure drops obtained with encapsulated filters, i.e. with filter dilution excluded to heighten the comparison between the two models. If filter dilution had been included, column dilutions similar to those given in Table 6 would have been obtained. In Table 8 it is readily apparent that the dilutions predicted by the capillary flow model are less than those given by the pressure drop equations which do not specify the flow regime through the paper. The capillary flow dilutions are about $68-72 \%$ of the other values for brands $A$ through $G$, and decrease to $60 \%$ for

\begin{tabular}{|c|c|c|c|c|c|c|c|}
\hline \multirow{2}{*}{\multicolumn{2}{|c|}{ Brand }} & \multirow{2}{*}{$\begin{array}{c}\text { Cigarette } \\
\text { length } \\
(\mathrm{mm})\end{array}$} & \multicolumn{2}{|c|}{ Pressure drop $\left(\mathrm{mm} \mathrm{H}_{2} \mathrm{O}\right)$} & \multirow{2}{*}{$\begin{array}{c}\text { Calculated } \\
\text { porosity } \\
(\mathrm{mm} \Delta \mathrm{p})\end{array}$} & \multirow{2}{*}{$\begin{array}{c}\text { Measured } \\
\text { porosity } \\
(\mathrm{mm} \Delta \mathrm{p}) \\
\end{array}$} & \multirow{2}{*}{$\begin{array}{c}\text { Calculated } \\
\text { Observed } \\
(\%)\end{array}$} \\
\hline & & & encapsulated & unencapsulated & & & \\
\hline G & normal & 80 & 138 & 134 & 0.0047 & 0.0049 & 96 \\
\hline G & normal & 85 & 135 & 131 & 0.0052 & 0.0040 & 130 \\
\hline$H$ & perforated & 84 & 119 & 112 & 0.0151 & 0.0157 & 97 \\
\hline & perforated & 84 & 109 & 103 & 0.0200 & 0.0158 & 127 \\
\hline & & & & & & \multicolumn{2}{|c|}{ average $\overline{113}$} \\
\hline
\end{tabular}
brand $\mathrm{H}$ which is wrapped in a perforated paper. This trend is in line with the concept that part of the flow through cigarette paper is like that through an orifice, which would give more flow and hence more dilution at any given pressure drop. Thus the capillary flow model is not adequate to describe the dilution occurring in cigarettes, and hence dilutions calculated from measured paper porosities via this route will be somewhat low. $\mathrm{On}$ the other hand, dilutions calculated directly from pressure drops appear to be close to the actual values.

Table 7. Comparison of paper porositles. 
Table 8. Comparison of dilution models (tobacco column dilutions without filter dilution).

\begin{tabular}{|c|c|c|c|c|}
\hline & & & Percer & ilution \\
\hline & and & column & & Pressure \\
\hline A & vented & 53 & 4.3 & 6.0 \\
\hline $\mathbf{B}$ & vented & 53 & 7.4 & 10.6 \\
\hline C & vented & 54 & 9.1 & 13.4 \\
\hline D & vented & 52 & 10.7 & 15.7 \\
\hline$E$ & vented & 55 & 10.6 & 15.5 \\
\hline $\mathbf{F}$ & porous tipping & 53 & 10.9 & 16.0 \\
\hline $\mathbf{G}$ & non-vented & 55 & 9.0 & 12.5 \\
\hline $\mathbf{G}$ & non-vented & 60 & 9.9 & 14.5 \\
\hline H & non-vented & 52 & 18.6 & 31.1 \\
\hline$H$ & non-vented & 53 & 20.4 & 34.2 \\
\hline
\end{tabular}

To summarize, it is found that:

1. Dilution levels can be adequately determined by combinations of encapsulated and unencapsulated pressure drop measurements.

2. Since pressure drop measurements are simple and nondestructive, they can be used to measure dilution levels in routine or semi-routine quality control.

3. The deliveries of major smoke components can be adequately predicted by considering dilution levels, changes in filtration efficiency, and changes in burning rate, and other factors such as diffusion.

4. When vented filters are employed, the degree of dilution increases above that measured on the unlit cigarette, but is essentially constant throughout the smoking process until the last puff or two when it increases further.

5. Vented filters can generally provide higher levels of dilution than porous and/or perforated papers, but the level of dilution is quire dependent not only on the hole area but on the location of the vents.

6. Although dilution is an effective means of reduction of smoke component deliveries, it is most effective when combined with filters of reasonable pressure drop and removal efficiency.

\section{SUMMARY}

Equations for calculating dilutions in vented cigarette filters and tobacco columns from pressure drop measurements are derived. These calculated dilutions are found to agree closely with those directly measured for a variety of commercial and experimental cigarettes wrapped with perforated and porous tipping and with different cigarette papers.

The effect of hole placement on dilution and cigarette pressure is estimated. The effects of filter dilution on particulate matter, condensate and carbon monoxide delivery are discussed. A method for measuring filter dilution dur- ing smoking by means of pressure drop measurements is outlined and results for a typical vented filter cigarette are shown and discussed. The use of pressure drop measurements for estimating paper porosity and amount of dilution in the tobacco column on finished cigarettes is outlined. The dilution obtained by this method was generally higher compared to the results found by a model based on a capillary flow regime, which suggests that flow through ordinary cigarette paper is a combination of capillary and orifice flow. The non-destructive nature and simplicity of pressure drop measurements make this method of measuring dilution useful in quality control of cigarette production.

\section{ZUSAMMENFASSUNG}

Es werden Gleichungen abgeleitet, mit denen die Verdünnung in ventilierten Cigarettenfiltern und Tabaksträngen aus Zugwiderstandsmeßwerten berechnet werden kann. Die errechneten Werte für die Verdünnung des Rauchstromes erwiesen sich als gut übereinstimmend mit Werten, die durch direkte Messung an verschiedenen für Versuchszwecke und für den Markt gefertigten Cigaretten mit unterschiedlichem Cigarettenpapier sowie porösem und perforiertem Belagpapier (Mundstüdksbelag) erhalten wurden.

Der Einfluß der Anordnung der Perforationslöcher auf die Verdünnung und den Zugwiderstand der Cigarette wird bestimmt. Die Auswirkungen der Filterventilation auf die Ausbeute an Partikelphase, Kondensat und Kohlenmonoxid werden diskutiert. Es wird ein Verfahren zur Messung der Filterventilation während des Rauchvorganges über die Zugwiderstandsmessung beschrieben, und die mit dieser Methode bei einer repräsentativen ventilierten Filtercigarette erzielten Ergebnisse werden dargelegt und diskutiert. Es wird gezeigt, wie die Messung des Zugwiderstandes zur Bestimmung der Papierporosität und des Ventilationsgrades im Tabakstrang an fertigen Cigaretten verwendet werden kann. Die mit diesem Verfahren erhaltenen Werte für die Verdünnung liegen im allgemeinen über den Ergebnissen, die mit Hilfe eines auf Kapillarströmung basierenden Modells erzielt werden; es ist daher anzunehmen, daß die Strömung durch gewöhnliches Cigarettenpapier aus einem linearen Anteil (capillary flow) und einem nichtlinearen Anteil (orifice flow) besteht. $\mathrm{Da}$ die Messung des Zugwiderstandes einfach ist und die Cigarette unversehrt läßt, eignet sich diese Methode bei der Cigarettenherstellung im Rahmen der Qualitätskontrolle gut für die Messung des Ventilationsgrades.

\section{RÉSUMÉ}

Des équations sont présentées qui permettent de calculer des dilutions par des filtres ventilés et des boudins de tabac à partir de mesures de la résistance au tirage. Ces dilutions calculées correspondent de très près à celles mesurées directement sur une variété de cigarettes commerciales et expérimentales enveloppées de papier de bout 
perforé et poreux et de différents papiers à cigarette. L'effet de la disposition des trous sur la dilution et le tirage de la cigarette a été évalué. Les effets de la dilution par le filtre sur le rendement en matière particulaire, condensat et monoxide de carbone sont exposés. Une méthode pour la mesure de la dilution par le filtre pendant le fumage au moyen de mesures de la résistance au tirage est décrite, et les résultats pour une cigarette avec filtre ventilé typique sont presentés et discutés. L'application de mesures de la resistance au tirage en vue de l'estimation de la porosité du papier et du taux de dilution dans le tabac sur cigarettes entières, est décrite également. La dilution obtenue par cette méthode est généralement plus élevée que celle obtenue avec un modèle basé sur le régime à flux capillaire, ce qui permet de supposer que le flux traversant un papier a cigarette ordinaire est une combinaison de flux capillaire et de flux d'orifice. Le caractère non destructif et la simplicité des mesures de la résistance au tirage rendent cette méthode de mesure de dilution très utile pour le contrôle de la qualité lors de la production des cigarettes.

\section{REFERENCES}

1. Norman, V.: Beitr. Tabakforsch. 7 (1974) 282-287.

2. Reynolds, J. H., and J. P. Wheeler: Paper presented at 30th 'Tobacco Chemists' Research Conference, Nashville, Tenn., Oct. 18-20, 1976.

3. Fordyce, W. B., J. W. Hughes and M. G. Ivinson: Tob. Sci. 5 (1961) 70-75.

4. Keith, C. H., J.O. Dalton and M. L. Reynolds: Paper presented at 21st 'Tobacco Chemists' Research Conference, Durham, N. C., Oct. 19-20, 1967.

5. Reif, H.: Fachliche Mitteilungen der Austria Tabakwerke No. 16, 1975, 318-320.

6. Meyer-Abich, K.: Beitr. Tabakforsch. 3 (1966) 307329.

7. Baker, R. R.: Beitr. Tabakforsch. 8 (1975) 124-131.

8. Parker, J. A., and R. T. Montgomery: Beitr. Tabakforsch. Int. 10 (1979) 1.

9. Selke, W. A., and J. H. Mathews: Beitr. Tabakforsh. Int. 9 (1978) 193-200.

10. Overton, J. R.: Beitr. Tabakforsch.7 (1973) 117-120.

11. Keith, C. H.: Recent Advances in Tobacco Science 4 (1978) 25-45.

12. Keith, C. H., and D. G. Vidkroy: Paper presented at 30th 'Tobacco Chemists' Research Conference, Nashville, Tenn., Oct. 18-20, 1976.

13. Morie, G. P.: Tob. Sci. 20 (1976) 175-176.

14. Baker, R. R., and R. A. Crellin: Beitr. Tabakforsch. 9 (1977) 131-140.

15. Owen, W. C., and M. L. Reynolds: Tob. Sci. 11 (1967) 14-17.

16. Muramatsu, M., T. Mikami, N. Naito and H. Tomita: Beitr. Tabakforsch. 9 (1977) 141-152.

17. Durocher, D.F., C.F. Mattina and W. A. Selke: Beitr. Tabakforsch. Int. 9 (1978) 201-207.

Author's address:

Celanese Fibers Company,

Researd Department,

P.O. Box 32414,

Charlotte, N.C., 28232, U.S.A.

For appendix see facing page. 


\section{Appendix}

\section{DERIVATION OF DILUTION EQUATIONS}

1. Assumptions: Pressure drop is proportional to flow rate and length, i. e. according to Darcy's Law for viscous flow. Pressure drops are additive.

2. For a single row of vent holes

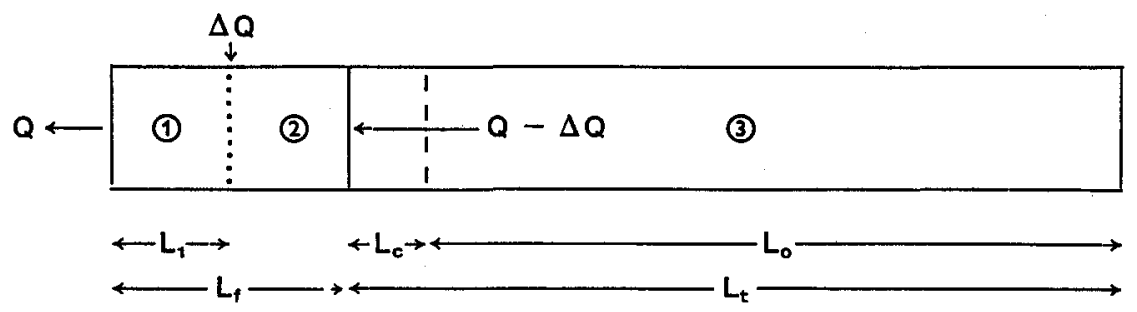

$$
\begin{aligned}
& \Delta p_{0}=\Delta p_{1}+\Delta p_{2}+\Delta p_{3} \\
& \Delta p_{1}=K_{1} \cdot L_{1} \cdot Q \\
& \Delta p_{2}=K_{f} \cdot\left(L_{f}-L_{1}\right) \cdot(Q-\Delta Q) \\
& \Delta p_{3}=K_{t} \cdot L_{t} \cdot(Q-\Delta Q)
\end{aligned}
$$

\section{Therefore:}

$\begin{aligned} \Delta p_{0}= & K_{t} \cdot L_{f} \cdot Q-K_{t} \cdot\left(L_{f}-L_{1}\right) \cdot \Delta Q+ \\ & +K_{t} \cdot L_{t} \cdot Q-K_{t} \cdot L_{t} \cdot \Delta Q\end{aligned}$

but:

$\Delta p_{c}=K_{f} \cdot L_{f} \cdot Q+K_{t} \cdot L_{t} \cdot Q$

$\Delta p_{f}=K_{f} \cdot L_{f} \cdot Q$

so:

$\Delta p_{0}=\Delta p_{f} \cdot \frac{L_{1}}{L_{f}} \cdot \frac{\Delta Q}{Q}+\Delta p_{c}-\Delta p_{c} \cdot \frac{\Delta Q}{Q}$

Rearranging to give equation 1 :

$\frac{\Delta Q}{Q}=\frac{\Delta p_{0}-\Delta p_{o}}{\Delta p_{b}-\frac{L_{1}}{L_{f}} \cdot \Delta p_{f}}$ where:

$$
\begin{aligned}
& \Delta p_{0}=\text { cigarette pressure drop - unencapsulated } \\
& \Delta p_{1}=\text { pressure drop in region } 1 \\
& \Delta p_{2}=\text { pressure drop in region } 2 \\
& \Delta p_{3}=\text { pressure drop in region } 3 \\
& \mathrm{~K}_{\mathrm{f}}=\text { filter impedance } \\
& K_{t}=\text { tobacco column impedance } \\
& \left.\begin{array}{l}
L_{1} \\
L_{t} \\
L_{t}
\end{array}\right\}=\text { lengths as indicated } \\
& Q=\text { exit flow rate } \\
& \Delta Q=\text { diluting flow rate } \\
& \Delta p_{c}=\text { cigarette pressure drop - filter encapsulated } \\
& \Delta p_{f}=\text { filter pressure drop - encapsulated }
\end{aligned}
$$

3. For $n$ rows of holes spaced $\Delta L \mathrm{~mm}$ apart with flow dQ in each row

$$
\begin{aligned}
& \Delta p_{1}=K_{f} \cdot L_{1} \cdot Q \\
& \Delta p_{2}=K_{f} \cdot \Delta L \cdot(Q-d Q) \\
& \Delta p_{3}=K_{f} \cdot \Delta L \cdot(Q-2 d Q) \\
& \Delta p_{n}=K_{f} \cdot \Delta L \cdot(Q-(n-1) \cdot d Q) \\
& \Delta p_{n+1}=K_{f} \cdot\left(L_{t}-L_{1}-(n-1) \cdot \Delta L\right) \cdot(Q-n d Q) \\
& \Delta p_{n+2}=K_{t} \cdot L_{t} \cdot(Q-n \cdot d Q)
\end{aligned}
$$

but:

$$
\begin{aligned}
& n \cdot d Q=\Delta Q \\
& \Delta p_{0}=\sum_{i=1}^{n+2} \Delta p_{i}
\end{aligned}
$$

Therefore:

$$
\begin{aligned}
\Delta p_{0}= & \sum_{i=1}^{n-1} K_{f} \cdot \Delta L \cdot(Q-i d Q)+K_{f} \cdot L_{f} \cdot Q-K_{f} \cdot(n-1) \cdot \Delta L \cdot Q-K_{f} \cdot L_{f} \cdot \Delta Q+ \\
& +K_{f} \cdot L_{t} \cdot \Delta Q+K_{f} \cdot(n-1) \cdot \Delta L \cdot \Delta Q+K_{t} \cdot L_{t} \cdot Q-K_{t} \cdot L_{t} \cdot \Delta Q .
\end{aligned}
$$


Substituting for $K_{f}$ and $K_{t}$ as before and evaluating the sum of the series, we get:

$\Delta p_{0}=\Delta p_{f} \cdot \frac{(n-1)}{2} \cdot \frac{\Delta L}{L_{f}} \cdot \frac{\Delta Q}{Q}+\Delta p_{f} \cdot \frac{L_{1}}{L_{f}} \cdot \frac{\Delta Q}{Q}-\Delta p_{c} \cdot \frac{\Delta Q}{Q}+\Delta p_{c}$.

which yields equation 2:

$\frac{\Delta Q}{Q}=\frac{\Delta p_{c}-\Delta p_{0}}{\Delta p_{c}-\frac{L_{q}}{L_{f}} \cdot \Delta p_{f}-\frac{(n-1)}{2} \cdot \frac{\Delta L}{L_{f}} \cdot \Delta p_{t}}$

4. As $\Delta \mathrm{L}$ becomes smaller and $\mathrm{n}$ becomes larger, we approach a porous plug wrap situation. If this extends the length of the filter, $(n-1) \cdot \Delta L$ equals $L_{f}-L_{1}$ where $L_{1}$ is now the length enclosed in a holder. Substituting in equation 2 gives:

$\frac{\Delta Q}{Q}=\frac{\Delta p_{c}-\Delta p_{o}}{\Delta p_{c}-\frac{L_{1}}{L_{f}} \cdot \Delta p_{f}-\frac{\left(L_{f}-L_{1}\right)}{2 L_{f}} \cdot \Delta p_{f}}$

or equation 3:

$\frac{\Delta Q}{Q}=\frac{\Delta p_{c}-\Delta p_{0}}{\Delta p_{c}-\frac{\left(L_{i}+L_{f}\right)}{2 L_{f}} \cdot \Delta p_{f}}$

5. The same concept applies to a tobacco column with an unencapsulated length of $L_{0}$ and an overwrapped or encapsulated length of $L_{c}$. The fully encapsulated pressure drop is $\Delta p_{e}$, while the open pressure drop is $\Delta p_{c}$. The exit flow rate $Q$ is now the flow leaving the tobacco column and entering the filter.

Again summing pressure drops, we get:

$\Delta p_{c}=K_{f} \cdot L_{f} \cdot Q+K_{t} \cdot L_{c} \cdot Q+\sum_{i=t}^{n} K_{t} \cdot \Delta L \cdot(Q-i d Q)$

$\Delta p_{f}=K_{f} \cdot L_{f} \cdot Q$

$\Delta p_{0}=K_{f} \cdot L_{f} \cdot Q+K_{t} \cdot L_{c} \cdot Q+K_{t} \cdot L_{0} \cdot Q$

Introducing the sum of the series and considering that when $n$ is very large $n \cdot \Delta L \cong(n+1) \cdot \Delta L=L_{0}$ and that $n \cdot d Q=\Delta Q$

$\Delta p_{c}=K_{f} \cdot L_{f} \cdot Q+K_{t} \cdot L_{c} \cdot Q+K_{t} \cdot L_{0} \cdot Q-\frac{K_{t} \cdot L_{0} \cdot \Delta Q}{2}$.

Since the first three terms on the right side equal $\Delta p_{e}$, we get:

$\Delta p_{0}-\Delta p_{c}=\frac{K_{t} \cdot L_{0} \cdot \Delta Q}{2}$

but:

$K_{t}=\frac{\Delta p_{e}-\Delta p_{f}}{\left(L_{0}+L_{c}\right) \cdot Q}$

so:

$\Delta p_{0}-\Delta p_{c}=\frac{L_{0} \cdot\left(\Delta p_{e}-\Delta p_{f}\right)}{2\left(L_{o}+L_{c}\right)} \cdot \frac{\Delta Q}{Q}$.

Rearranging gives equation 4:

$\frac{\Delta Q}{Q}=\frac{2\left(\Delta p_{0}-\Delta p_{c}\right) \cdot\left(L_{0}+L_{c}\right)}{\left(\Delta p_{0}-\Delta p_{f}\right) \cdot L_{0}}$.

If the cigarette is unflitered $\Delta p_{o}$ is substituted for $\Delta p_{c}$ and $\Delta p_{f}=0$.

6. If filter dilution is also present, the flow exiting the tobacco column will be less than the mouth end exit flow. If $Q^{\prime}$ equals the tobacco column exit flow and $Q$ the mouth end exit flow, then $Q^{\prime}=\left(1-D_{f}\right) \cdot Q$ where $D_{f}$ is the fractional filter dilution.

Substituting $Q^{\prime}$. for $Q$ in equation 4 and rearranging gives equation 5 :

$\frac{\Delta Q}{Q}=\frac{2\left(\Delta p_{0}-\Delta p_{c}\right) \cdot\left(1-D_{f}\right) \cdot\left(L_{0}+L_{c}\right)}{\left(\Delta p_{0}-\Delta p_{f}\right) \cdot L_{0}}$

7. Equation 6 is merely an expression of the additivity of dilutions for various parts of the cigarette, provided that the dilution of the tobacco column is calculated using equation 5 rather than 4. 